\title{
Integrated Measurements for Biodiversity Conservation in Lower Prut Basin
}

\author{
Florin Vartolomei
}

Additional information is available at the end of the chapter

http://dx.doi.org/10.5772/48683

\section{Introduction}

To establish protected areas together with an efficient management is a necessity as: protected areas are representative of natural and semi-natural ecological ecosystems that can be valued and monitored to a certain degree in relation to their state as well. Such ecosystems are the main components of the natural capital providing resources and services for the socioeconomic development; protected areas are zones where it is possible to develop the knowledge necessary for passing from the transition period to a sustainable development model; protected areas are "out-door lessons" of education on nature's role and the necessity of nature's conservation and sustainable development. Differences of terminology can be eliminated simply, by using IUCN system of classification whose main aim is to manage the protected area. In the system there are 6 categories of protected areas, which also involve a varying degree of human intervention - from nonexistent (category I-a and $\mathrm{I}-\mathrm{b}$ ) to a higher degree (category V). All categories are the same importance and relevance for biodiversity conservation. According to the Urgency Ordinance No. 236/2000 on the system of protected natural areas, conservation of natural habitats and wild flora and fauna, in our country the accepted categories of natural protected areas defined depending on the assigned management goals are the following: scientific reserve, natural reserve, national park, natural park, natural's monument, biosphere reserve, wet area importance (RAMSAR site), site of the world natural inheritance.

\section{About study area}

The Prut River is the last largest tributary of the Danube, before it discharges into the Black Sea (through the Danube Delta). The Prut river springs in Ukraine, flows through the border area between Romania and Republic of Moldova, down to the point where it enters the Danube (Figure 1). 
The Prut river is an allochthon river that originates in the Woody Carpathians in Ukraine. Between Orofteana and the confluence with the Danube on the lengh of $946 \mathrm{~km}$, it drains a basin of 28,463 sqkm. At Czernowitz (in Ukraine) the Prut river has a multi-annual average flow of $73.62 \mathrm{mc} / \mathrm{s}$, it grows up to Fălciu at $103.48 \mathrm{mc} / \mathrm{s}$, and then it comes down to $85.3 \mathrm{mc} / \mathrm{s}$, because of the lateral losses [1].

\section{Review of current river management practices and assessment of anthropogenic activities}

From hydrological point of view the following data have been gathered for the Prut River Basin, part on the Romanian territory (figure 1). Main attitude at the entrance in Romania is about $140 \mathrm{~m}$ (above Black Sea. level). Main altitude at the discharge in Danube about $15 \mathrm{~m}$ (Black Sea). Average multiannual runoff is $88 \mathrm{~m}^{3} / \mathrm{s}$, maximum multiannual runoff (19522010) is $4240 \mathrm{~m}^{3} / \mathrm{s}$ in 2008 at Radauti-Prut hydrometric station. Minimum multiannual runoff (1952-2010) is $7.6 \mathrm{~m}^{3} / \mathrm{s}$. On the Romanian territory (at the entrance in the country ) for 19522010 period the data referring to the flow characteristics are included in the table 1 below:

\begin{tabular}{|c|c|c|c|c|c|c|c|}
\hline $\begin{array}{c}\text { Hydrometric } \\
\text { station }\end{array}$ & $\begin{array}{c}\text { Rădăuți- } \\
\text { Prut }\end{array}$ & Ştefăneşti & Ungheni & Dorohoi & Todireni & $\begin{array}{c}\text { Bădeni- } \\
\text { Hârlău }\end{array}$ & $\begin{array}{c}\text { Cărpinați- } \\
\text { Victoria }\end{array}$ \\
\hline river & Prut & Başeu & Prut & Jijia & Sitna & Bahlui & Jijia \\
\hline $\mathbf{m}^{3} / \mathbf{s}$ & 78,28 & 1,94 & 85,97 & 0,66 & 2,03 & 0,44 & 6,65 \\
\hline $\begin{array}{c}\text { Hydrometric } \\
\text { station }\end{array}$ & Todireni & Podu Iloaie & $\begin{array}{c}\text { Podu } \\
\text { lloaie }\end{array}$ & Iaşi & Iaşi & Murgeni & Fârţăneşti \\
\hline river & Jijia & Bahlui & Bahluieț & Bahlui & Nicolina & Elan & Covurlui \\
\hline $\mathbf{m}^{3} / \mathbf{s}$ & 2,21 & 1,18 & 1,08 & 3,01 & 0,43 & 0,49 & 0,56 \\
\hline
\end{tabular}

Table 1. The flow characteristics during 1952-2010 in the Romanian section of the basin

As the lower Prut area is situated in the Eastern part of the country, the climate is influenced by the vicinity with the Carpathian Mountains in the West. Moldavian plain in the East and the river Danube meadow the South. This creates some small changes in comparison with the average level at the normal level for temperature, precipitation and winds. The average precipitation is between $690 \mathrm{~mm}$ (1989) - $515 \mathrm{~mm}$ (1993)-632,27 $\mathrm{mm}$ (1996) with an average net flow of $174 \mathrm{~mm}$ (1988) -130 mm (1992) and 159,45 mm (1996).

The main human activities for which water use demands normally identified are: hydrotechnical works and flood protection schemes, source for water supply, for urban and rural use, electrical energy, agriculture, fisheries, industry and others [2].

\section{General data}

Prut basin, through the variety of geomorphic elements, of flora and fauna, is permanently subjected to the researches of various experts from Romania, Republic of Moldova or other countries. 


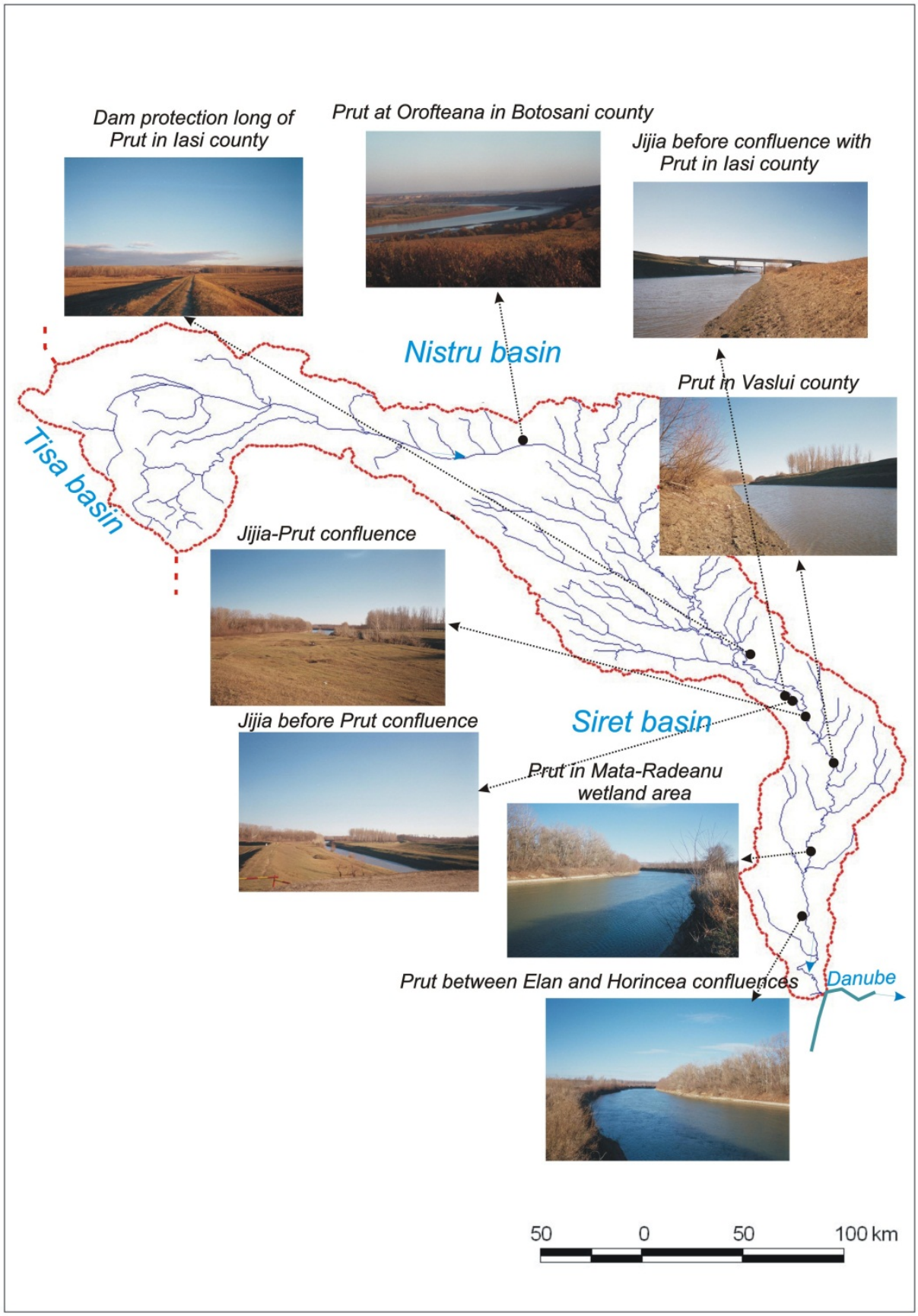

Figure 1. Prut basin - general overview 
With regard to forests diversity, different kinds of wood trees can be found which are mostly specific for silvostepa, with alternation of plains, hills and forests. The structure of species composition is the following: resinous trees $30 \%$ (spruce fir, fir, pine tree and others) and deciduous trees-70\% (fagus, representatives of Querqus family., different soft and hardwoods).

Owing to the Law no 18/1991 (also called Land Restitution Law) within the Galati county a surface of 5,283 ha was given back to the former land forest owners.

The percent of forestation within the county is very low about $8 \%$ of the county total surface, being necessary to increase the forest surface through the forestry plans works or through ecological reconstruction [3].

Along the lower Prut river there is a forested corridor very well preserved and managed with typical tree species, playing a multifunctional role. Forest functions have actually diversified over time and as a result forest management practices are increasingly having to meet multipurpose requirements including such environmental functions as sustainability nature conservation and water buffer zone for flood management, as well as community (recreation, culture and aesthetics) and production functions.

With regard to the fauna, the most specific species are determined by the steppe and silvostepa zones. The most comune are rabbits, around squirrel, hamster and many others. From the bird's family can be mentioned bustard, quail, partridge and large types of flying birds. As representatives from other faunistic families can be mentioned fox, wolf, wild boar, as well as dear, squirrels, etc. There is a number of species (flora, fauna and forests) and locations which have been protected by law starting from 1930, which are organized as protected areas and monuments of nature.

The economic, activities in the region during the last several decades deteriorated the environmental balance in the basin area. Urbanization, industrial development, intensive agricultural practices, high density of railway and road networks, new reservoirs and other hydrotechnical works in the flood plain of the river, brought about a considerable loss of floodplain habitat and wetlands. Prut River management and rehabilitation of the crossborder wetlands can only be approached internationally.

\section{Key species of terrestrial and aquatic area of the Prut river}

The key species are represented by plants, butterflies, fish and birds [4].

Plants: the Tamarix ramoissima occurs on virgin soil habitats along the lower Prut. This area also offers narrow riparian pioneer arcas that are favorable to white willow (Salix alba) succession. The water chestnut (Trapa natans) occurs on the lower Prut, due to water eutrophication it has dramatically decreased and counts among the Red List species of this area.

Butterflies: the distribution map of the Large Copper shows many occurrences along the central Prut valley, a continuous occurrence along the whole river is very probable. The 
occurrence of the Danubian Purple Emperor is very probable for the lower Prut, because it has been found in the both adjacent lower Siret floodplain and the Danube Delta.

Fish: European mud-minnow occurs on the lower Prut where the floodplains provide sufficient adequate habitats. Blue bream occurs regularly in the river downstream of the dam Stanca Costesti (a well-operating communication between the river and floodplain waters is guaranteed in this section). Crucian carp and mud load occur in the lower river, where adequate aquatic habitats for the Crucian carp have been preserved.

Birds: about the White-tailed eagle there is no breeding occurrence on the Prut.

\section{General frame and measurements for biodiversity protection}

The Lower Meadow of Inferior Prut River Natural Park includes all the flood meadow of Prut river on the administrative territory of Galați county. The Lower Meadow of Inferior Prut River Natural Park has the endorsement of CMN 19/Cj/18.02.2003.

The planning maps of UP V Prut Meadow were drawn up by SILVAPROIECT, in 1995. The area of the Natural Park fits the type of habitat formed of: Natural eutrophic lakes with a Magnopotamion or Hydrocharition-type vegetation (Natura 2000 code of habitats: 3150) and lakes or dirty grey to blue - green water ponds, more or less turbid, especially rich in basic substances ( $\mathrm{pH}$ usually higher than 7), many freely floating Hydrocharition communities being present at the surface or, in case of the deep systems and open water surfaces, the Hydrocharition communities are associated to the submersed vegetation formed of large cormophytes (Magnopotamion).

For all the types of existing habitats housing a large variety of fauna (especially avifauna), sedentary as well as migrating or passing fauna, the Maţa - Rădeanu humid area, with a surface of 386 ha, is similar to the special preservation areas from the Danube Delta. Other areas on Prut river may be considered similar the this one (Pochina lake, the area where dams are being built, between Vlădeşti and Giurgiuleşti customs point, Prut Isle, Brateş lake) [5].

Romania is part of the the Natura 2000 European Network (SPAs - Special Protection Areas and SCIs - Sites of Community Importance) aiming to protect wildlife and its habitats, 2 whose surface is not definitively established.

Also, the national authority responsible for the protected areas in Romania is hardly starting the process (January, 2010) of handing out the Natura 2000 sites to different legal entities (NGOs, economic agencies, research institutes, local authorities etc.) in order to manage them.

GIS techniques and GPS means were used for the inventory and Land Register records of these types of surfaces and also for the integration in digital formats of the protected area limits at a European level [6, 7]. 


\section{Inventory of wetlands and floodplain habitats}

In 1998 "Romanian Waters" National Company the main manager of the water resources from Romania has started the preparation at the request of the Ministry of Water Forest and Environment Protection the inventory of the wetland and floodplains at national level including the potential for restoration according with the particular case from Romania where the process of land restitution to the previous owners is in the second step of application.

In order to determine the wetland conservation potential in the Danube River Basin, an evaluation study of wetlands and floodplains areas was done by an international consortium under the UNDP/GEF Assistance.

Also, at the national level an inventory of the wetlands and floodplains was done including all existing natural wetlands or wetlands for which the initial situation was changed.

In both reports the Prut catchment area was presented with a large number of existing wetlands and also with a large restoration potential.

Out of about 200 wetlands recorded for whole Prut basin (many of them are less than 1 sqkm surface) a number of 19 wetlands were selected and discussed in the inception phase. This is included in the table 2. Some of these wetlands are still under the natural conditions (10) and the rest were modified to be used by agriculture [8].

It has to be mentioned that several wetlands which in present are in natural stage are included or will be included in the List of Protected Areas under the legislation preservation. In this regard the planning of wetlands and floodplains rehabilitation is underdevelopment and will depend by the finalization of the land restitution action. In the lower Prut basin within the Vaslui and Galati counties the following protected areas are to be mentioned (Table 3) [9].

Among the protected areas within Galati county, according to the criteria of habitat identification, three of them (Prut Ostrov, Lower Prut river meadow and Vlascuta swamp) have been indicated to include some wetlands as well (Figure 2) [10].

To this point bellow is presented a more detailed situation and characterization of them.

a. For the Prut Ostrov which is an eyot and has been included in the $4^{\text {th }}$ category of protected areas by the County Council from 1994. The Prut Ostrov is located in the lower Danube river, near to the Prut river. As types of vegetation, the forest and specific wetland vegetation were identified.

Regarding the main habitats of the protected area, habitats of freshwater/wetlands and forest are present. The surface of main types and surface of habitats is described in table 4 .

The fauna is represented by mammals, birds, reptiles, frogs, fishes and representatives of Nevertebrata Fillum. 


\begin{tabular}{|c|c|c|c|c|c|}
\hline No. & County & Location & River & $\begin{array}{l}\text { Surface } \\
(\mathrm{sqkm})\end{array}$ & $\begin{array}{c}\text { Wetlands } \\
\text { conditon/usage }\end{array}$ \\
\hline 1 & Iasi & Dranceni & Drinceni- & 2.70 & agriculture \\
\hline 2 & Iasi & Albita-Falciu & Poganesti & 24.3 & agriculture \\
\hline 3 & Vaslui & Albita-Falciu & Stanilesti & 36.8 & agriculture \\
\hline 4 & Vaslui & Albita-Falciu & Banului lake & 56.55 & agriculture \\
\hline 5 & Vaslui & Albita-Falciu & Berezeni & 40.20 & agriculture \\
\hline 6 & Vaslui & Albita-Falciu & Falciu & 28.70 & agriculture \\
\hline 7 & Vaslui & Bata- Rinzesti & Ranzesti & 3.00 & agriculture \\
\hline 8 & Vaslui & Urlati & Elan & 0.75 & natural \\
\hline 9 & Vaslui & Gusitei & Elan & 2.30 & natural \\
\hline 10 & Vaslui & Poste Elan & Elan & 0.75 & natural \\
\hline 11 & Vaslui & Paicani & Elan & 1.25 & natural \\
\hline 12 & Vaslui & Giurcani & Elan & 0.30 & natural \\
\hline 13 & Vaslui & Murgani & Elan & 0.50 & natural \\
\hline 14 & Galati & Galati - Vadoni & Prut & 75 & natural \\
\hline 15 & Galati & Rogojani & Horincea & 1.50 & natural \\
\hline 16 & Galati & Vladesti & Prut & 269 & agriculture \\
\hline 17 & Galati & Bratesul de Sus & Prut & 58.01 & agriculture \\
\hline 18 & Galati & Bratesul de Jos & Prut & 97.47 & agriculture \\
\hline 19 & Galati & Badalani & Prut and Danube & 17.86 & agriculture \\
\hline 20 & Galati & Prut Ostrov (Prut island) & Prut and Danube & 56.6 & natural \\
\hline 21 & Galati & LowerPrut floodplain & Prut & $5,480.41$ & natural \\
\hline 22 & Galati & Vlascuta swamp & Prut & 41.8 & natural \\
\hline
\end{tabular}

Table 2. The wetlands within the Prut catchment area

Regarding the activities which occur within this protected area fishing, sporadic deforestation, hunting, different types of poaching. The impact of fishing, hunting and poaching activities according to action time the protected area is sporadic.

b. The Lower Prut river meadow. The vegetation of forest, pasture, floodplain and peat swamp, are characteristic for the vegetation type. Regarding the main habitats of the protected area, habitats of freshwater/wetlands/floodplain, herbal associations, lawns and bushes, forest, the Prut river on the Romanian territory are present (Figure 3). 


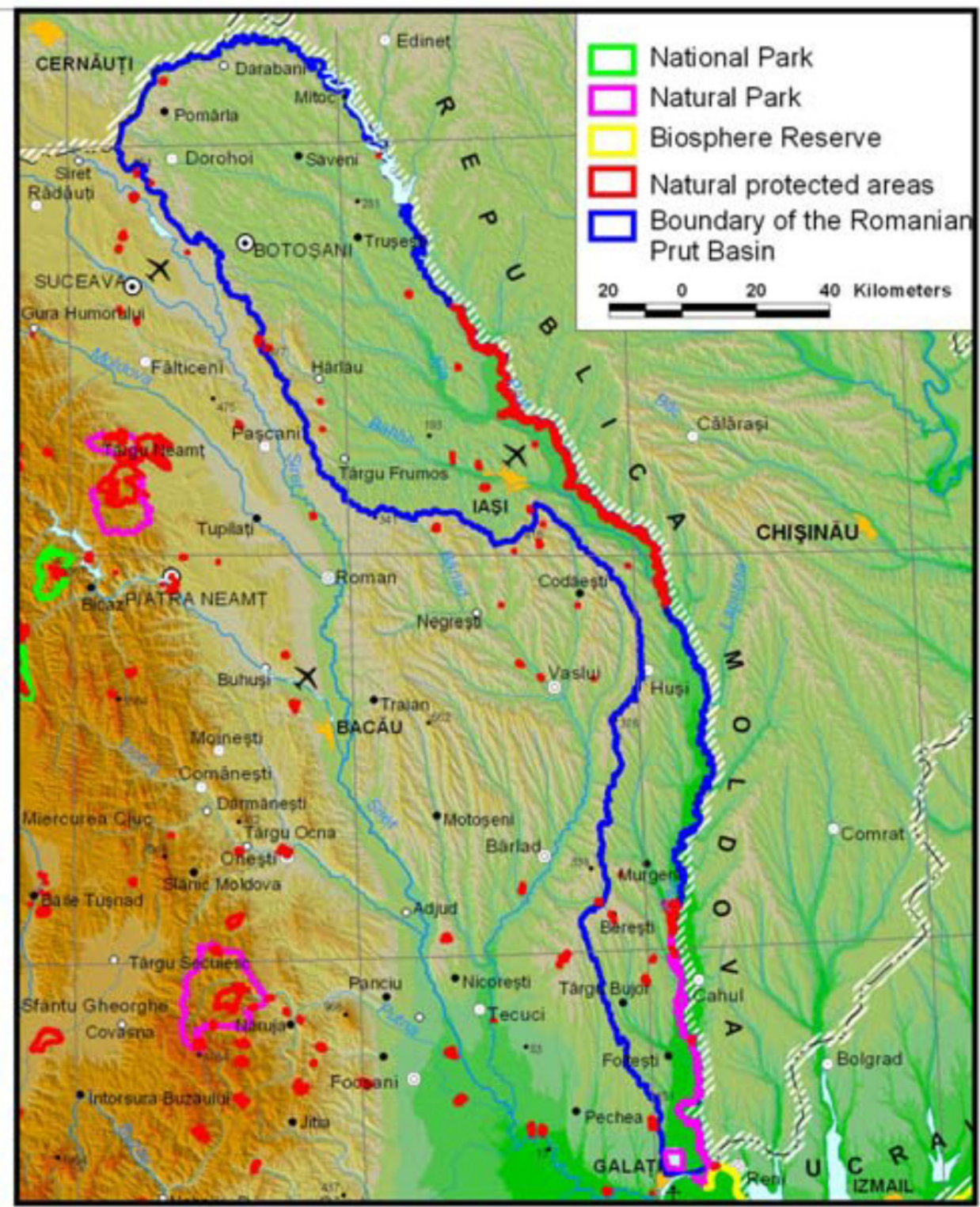

Figure 2. Natural Protected Areas in the Romanian Prut Basin 


\begin{tabular}{|c|c|c|c|}
\hline \multicolumn{4}{|c|}{ Vaslui county } \\
\hline No. & Natural reservation & Location (commune) & Surface (ha) \\
\hline 1 & Fossil area Malusteni & Malusteni & 1,000 \\
\hline 2 & Fossile place Nisiparia Hulubat & Vaslui & 250 \\
\hline 3 & Hill of Burcel & Miclesti & 1,200 \\
\hline 4 & Tanacu - Coasta Rupturile & Tanacu & 600 \\
\hline 5 & Badeana forest & Tutova & 12,670 \\
\hline 6 & Harboanca forest & Stefan cel Mare & 4,310 \\
\hline 7 & Balteni forest & Balteni & 2,200 \\
\hline 8 & Hay meadow Glodeni & Glodeni- Negrilesti & 600 \\
\hline \multicolumn{4}{|c|}{ Galati county } \\
\hline No. & Natural reservation & Location (commune) & Surface (ha) \\
\hline 1 & Sand dunes - Hanu Conachi & Hanul Conachi & 199.3 \\
\hline 2 & Garboavele forest & Galati & 220.4 \\
\hline 3 & Breana - Roscani forest & Baneasa & 78.3 \\
\hline 4 & Fossil place Tirighina/ Barbosi & Galati & 1.0 \\
\hline 5 & Fossil area rates & Tecuci & 1.5 \\
\hline 6 & Fundeanu forest & Draguseni & 110.7 \\
\hline 7 & Talasmani forest & Beresti & 20.0 \\
\hline 8 & Buciumeni forest & Buciumeni, Brahesesti & 71.2 \\
\hline 9 & Prut Ostrov & Ghimia Prut & 56.6 \\
\hline 10 & Potcoava swamp & Branistea & 49.0 \\
\hline 11 & Talabasca swamp & Tudor Vladimirescu & 130.0 \\
\hline 12 & Lacul fusilier Beresti & Beresti & 49.0 \\
\hline 13 & Lower Floodplain Prut & Cavadinesti & $5,480.41$ \\
\hline 14 & Pochina swamp/lake & Suceveni & 74.8 \\
\hline 15 & Vlascuta swamp/lake & Mascatani & 41.8 \\
\hline 16 & Pogonesti forest & Suceveni & 33.5 \\
\hline
\end{tabular}

Table 3. The protected areas within Lower Prut river countries

\begin{tabular}{|c|c|}
\hline Main types & Surface (ha) \\
\hline Habitats of freshwater/Wetlands & 20.5 \\
\hline Forests & 35.5 \\
\hline Total & 56 \\
\hline
\end{tabular}

Table 4. The surface of main types and surface of habitats in Ostrovul Prut

The surface of main types and surface of habitats are described in the table 5 bellow:

\begin{tabular}{|l|l|}
\hline Main types & Surface (ha) \\
\hline Habitats of freshwater/Wetlands & 25.5 \\
\hline Herbal associations/lawns and bushes & 31.5 \\
\hline Forests & $2,573.43$ \\
\hline The Prut river on the Romanian territory & 225 \\
\hline
\end{tabular}

Table 5. The surface of main types and surface of habitats in The Lower Prut river meadow 
The flora is specific floodplains and swamps being represented by Salix alba, Populus alba, Rosa canina, Satix fragila, Eqtasetum limosum, Typha angustifolia, Nymphae alba, Sagitaria sagitifolia, etc. The fauna is represented by species of birds, fish, reptiles, frogs, insects, mammals which are characteristic for wetlands biotopes.

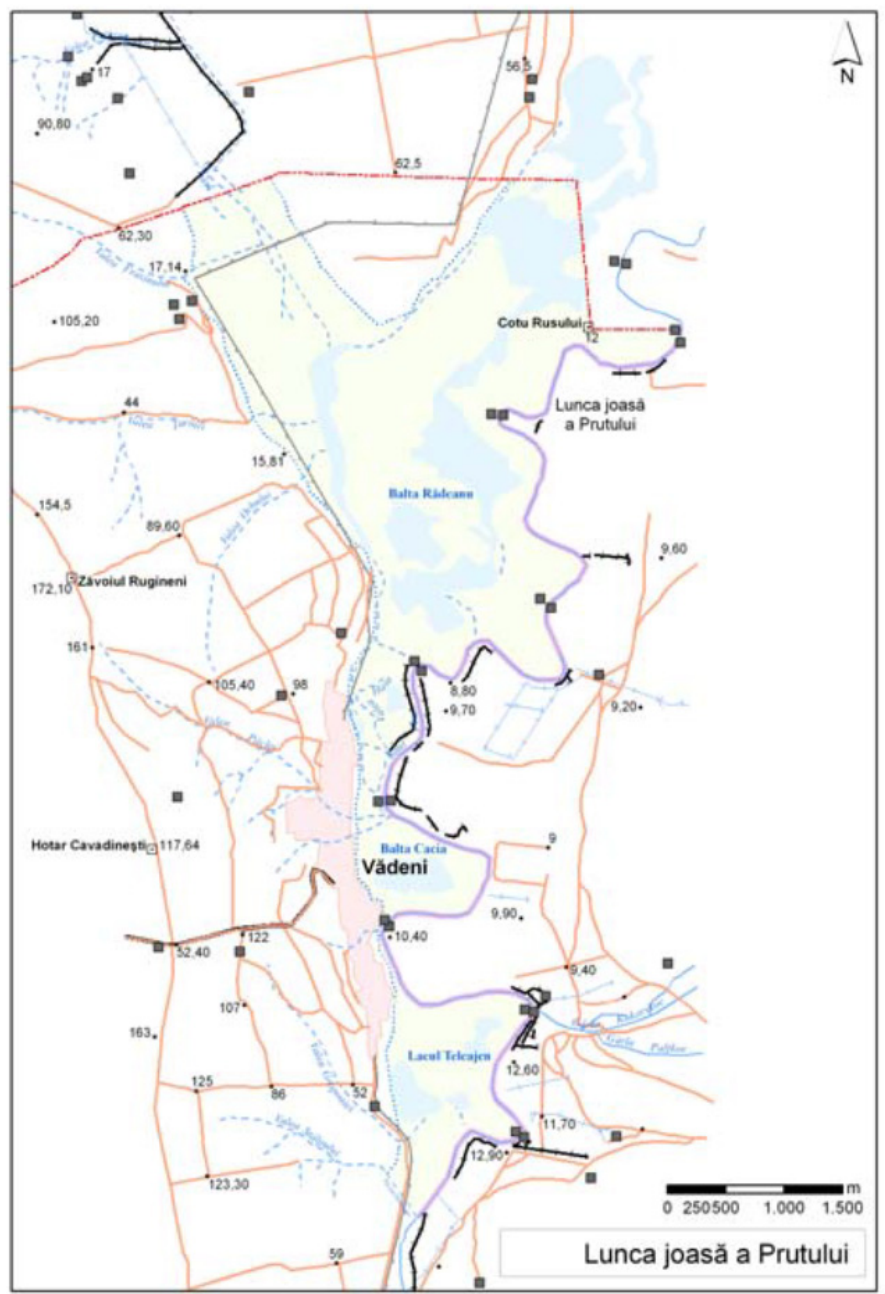

Figure 3. Lower Meadow of Prut River Natural Reserve

The Lower Prut river meadow represents an excellent habitat for more than 230 birds species/nesting, feeding and halt places, many of birds being protected by the international conventions. Fish species are represented by freshwater species, such as Misgurnus fosilis. Titca tica, Esox lucius, Cyprinu carpio, Silurus glanis, etc. The mammals are presented in a small number of species Ondrata yibethica, Vulpes vulpes. 
Regarding the activities which occur within this protected area fishing, deforestation, hunting, different types of poaching. The impact of fishing, deforestation according to their action time on the protected area is periodical hunting and poaching activities have a sporadically time action.

There have been recorded a number of activities with accidental character and which take place outside of the protected area and which have a negative impact on it (table 6 below):

\begin{tabular}{|l|l|l|}
\hline Impact Source & Pollutant & Types of affected environmental factors \\
\hline Fish ponds & Wastes & Water, soils \\
\hline Mata/Radeanau, Sovarca & Wastes & Water \\
\hline Vladesti, Brates & nutrients & Water \\
\hline
\end{tabular}

Table 6. Types of affected environmental factors in The Lower Prut river meadow area

This protected area is affected by periodical floods especially during the springs. The natural reserve Lower Prut river meadow has been proposed by the Environmental Protection Agency in 1999, in the frame "Green Corridor Of the Lower Danube" which is coordinated by the Research \& Design Institute "Danube Delta" and the Direction of Nature Conservation and Biological Diversity from the Romanian Environmental Ministry to be presented to the Romanian Academy and County Council in order to be official declared. In present is protected according to Annexe 1 of Law no 5/2000.

\section{c. Vlăşcuța swamp}

The vegetation of this protected area is typically for wetlands (100\%).The flora is represented by Typha angustifolia, Nymphae alba, Sagitaria sagitifolia, etc. The fauna, is characteristically for shallow swamp being made up of invertebrates, frogs, mollusks, reptiles, fish, birds and mammals communities. Regarding the activities which occur within this protected area fishing, hunting, different types of poaching have a sporadic character. There have been recorded a number of activities with accidental character and which take place outside of the protected area and have a negative impact on it (table 7 below).

\begin{tabular}{|l|l|l|}
\hline Impact Source & Pollutant & Types of affected environmental factors \\
\hline Crops culture & Fertilizers & Soils, groundwater \\
\hline Mesteacanis village & Wastes & Water, soils \\
\hline
\end{tabular}

Table 7. Types of affected environmental factors in Vlăşcuţa swamp area

\section{The special avifaunistic protected area}

\subsection{Stânca-Costeşti lake}

The Stânca-Costeşti Dam and hydropower station was built between 1974-1978 years, as a Romanian-Russian common project and is located between Costeşti (Moldova) and Stânca (Romania) (Figure 4). The main goal of building this power station was to protect villages down the Prut River from annual floods. 


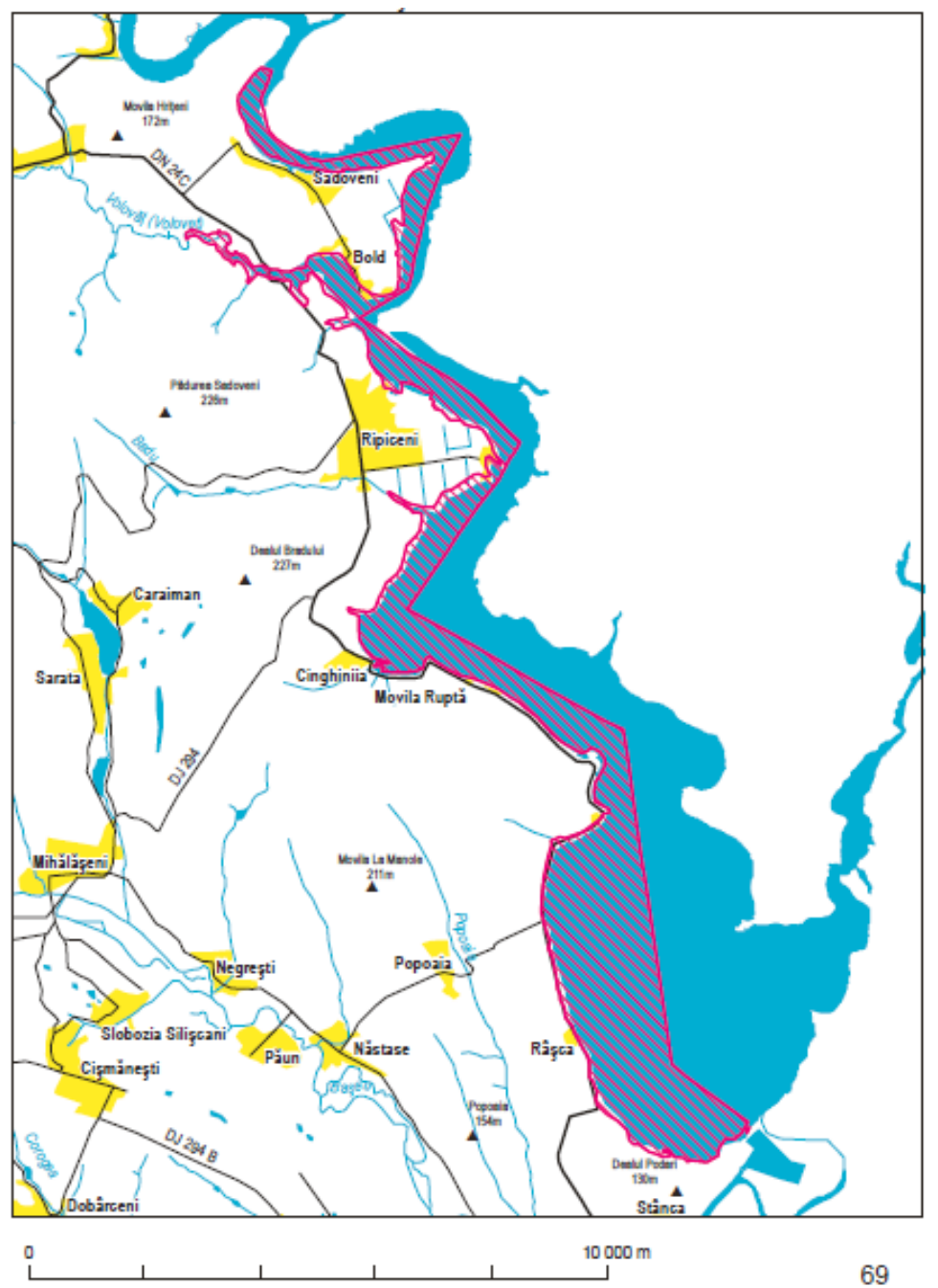

Figure 4. The special avifaunistic protected area - Stânca-Costeşti lake

The formation of the Stânca-Costeşti reservoir determined important changes of the ichthyofauna of the area. The main lake has lost the rheophil species (barbell, chub or wheatear), thus developing species with a mixed profile.

In Romanian section, a lot of hydrotechnical projects have been executed (damming, irrigation and draining canals etc.) on the Lower Prut, mainly on the territory of Galati county, downstream of Targu Bujor city. All these hydraulic works have affected the biodiversity of the aquatic and riverbank ecosystems, have restrained the natural habitats, have influenced the flow patterns of the river, have modified the local climate and have influenced the life of the local population. 
The development of industrial and agricultural activities in the whole catchment area of Prut have led to increased pollution by nutrients, organic substances, detergents, pesticides, heavy metals etc. All these factors adversely affected the water quality of the Prut river and its tributaries, and of the Lower Danube river and therefore have a direct impact upon the Black Sea.

The formation of the Stânca-Costeşti accumulation lake determined important changes of the ichthyofauna of the area.

The main lake has lost the rheophil species (barbell, chub or wheatear), thus developing species with a mixed profile.

The special avifaunistic protection area of Stânca-Costeşti lake stretches on 2,950 ha and comprises partially the localities of Mitoc, Liveni, Manoleasa, Manoleasa-Prut, Sadoveni, Ripiceni, and Stânca from Botoşani county.

The special avifaunistic protection area of Stânca-Costeşti lake has the endorsement of C.M.N. no. B 939/07.06.2004.

The pressure of economic development from the last 50 years in the area of Prut river, the protection measures against floods by building dams in the major river bed and the building of the hydrotechnical knot Stânca-Costeşti have been the causes of the transformation of the typical habitats in the humid areas at the border of Prut river, thus of the flood area favouring the breeding of fish and birds, endangering the ecological integrity of the area eco-system complex (Figure 5).

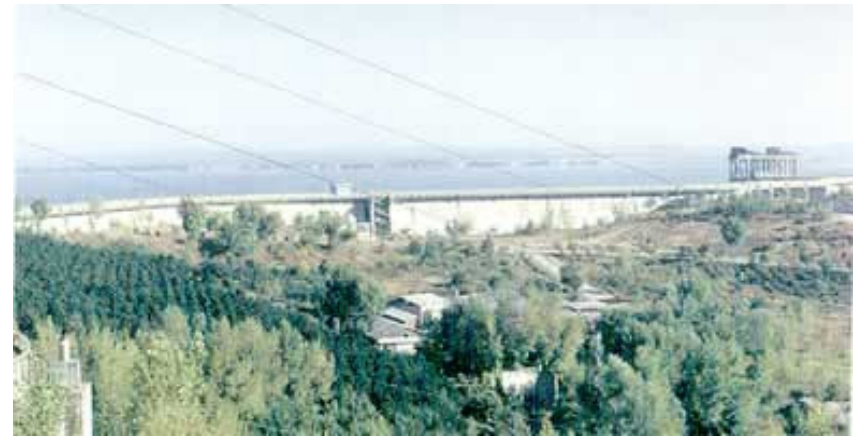

Figure 5. Stanca-Costesti lake (general view from Romanian bank)

The reduction in quantity and in quality of the aquatic fauna has been noticed, and this situation cannot be justified by pollution, because Prut river has a good status from a physical and chemical point of view, the concentrations not exceeding the standards set forth by Directive 98/83/EC.

At the moment, Prut river is facing a reduction of the fish quantities, according to the records made in 1947 when there were 37 species of fish compared to the 26 found nowadays [11]. 
The birds, more than any group of vertebrates, have a large living surface in the area presented in terms of the number of species as well as the number of individuals. The largest part of the birds found in the area are migrating species (44 species) representing international natural resources; among these, we mention the white stork, the bee-eater, the little egret, great crested grebe etc.

The implementation of some efficient measures for the protection of these populations and their habitats is necessary in order to comply with conventions and international agreements for the protection of wild flora and fauna, ratified by Romania. 31 sedentary species and 18 passing species are still living in this area.

From the total number of the species, 22 represent community interest, 27 species whose preservation needs the designation of avifaunistic protection areas and 39 species found under strict protection, according to Directive 79/409/EEC on the preservation of wild birds.

The project implementation for the declaration of the Stânca-Costeşti lake area as special avifaunistic protected area shall aim to preserve and restore the viable populations of birds specific to the humid climates, according to the stipulations of the Convention on the humid areas of international importance, especially as a habitat of aquatic birds, concluded at Ramsar in 1971 and ratified by Romania through law no. 5/1991.

In this context, the preservation of humid areas includes an important cross-border component, in the sense of the collaboration and adoption of a common and unitary strategy regarding the integrated administration and the management of the humid areas, the great economic, natural, scientific and recreational value [12].

Conferring in the future the official status of "cross-border protected site" to this area shall allow the establishment of restrictive measures for the protection and the preservation of biodiversity. Moreover, it shall encourage the preservation of the traditional practices of sustainable revaluation of the natural resources and the preservation of the social and cultural values of the river communities.

The European Union promotes a clear policy of cross-border collaboration for saving and perpetuating the natural and cultural heritage, supporting the interstate collaboration initiatives, in order to preserve the natural eco-systems, whose borders do not depend on the political or administrative ones.

\subsection{The Mața - Rădeanu complex of lakes}

The Mața - Rădeanu complex of lakes and ponds from the Lower Meadow of Prut River reservation (position 2.414 from appendix I of Law 5/2000) is an area that defines the establishment in the southern part of Prut basin of a special protection unit such as a Natural Park, as part of the Green Corridor of the Danube.

The complex of lakes and ponds in the north part of the Natural Park called Lower Meadow of the Inferior Prut River is developing through the fittings set on a surface exceeding 640 hectares. The initial usage category: pond (360 ha), meadow (71 ha), swamp (50 ha), 
unproductive (approx. 160 ha). This aquatic complex is located on the right bank of Prut river, between $\mathrm{km} \mathrm{113/landmark} 1255$ and $121+400 \mathrm{~m} /$ landmark 1252, in the junction area with Elan river, landmark 1253, on the territory of the commune of Cavadineşti - the village of Vădeni. In a natural status, at the maximum level of free floodwaters, the surface of the ponds exceeded 568 ha. The fishing fittings (568 ha) and the agricultural ones (78 ha) were built in the 1980. The land was divided in two separate groups by Elan river [13].

\section{The natural park from the southern sector of Prut basin}

Declaring the LOWER MEADOW OF THE INFERIOR PRUT RIVER NATURAL PARK in the southern part of Prut hydrographical basin is the result of the interaction between human activities and nature over time.

This protected area was created as a distinct area with a significant landscape value and with a great biological diversity where, through the maintenance of a harmonious interaction of man with nature and through the protection of the diversity of habitats and landscape, the traditional use of lands and some activities by the local population are encouraged (Figure 6-7).

In addition, the public is offered recreational activities and tourism and may unfold scientific, educational and cultural activities in the area.

\subsection{Ecological considerations}

The north group (Maţa pond, at the border of Vaslui county) made of two ponds (135 ha representing the low area of the pond and 57 ha - the high area of the pond) and the south group (Rădeanu pond: 342 ha of water +78 ha of agricultural surface).

Regarding Rădeanu pond, from the south-western part of Elan stream (inferior course), this presents features of integral natural area within which the water alternates with the reed, backwater, swampy surface, where the colonies of birds are present all year round.

The proposed surface as a special avifaunistic protection area is of 194 hectares.

Practically, because of the inadequate exploitation of numerous hydrotechnical works, especially because of the lack of financial resources, at the moment there are 148 ha of fishing ponds still functional (Figure 8).

The area of the Natural Park fits the type of habitat formed of: Natural eutrophic lakes with a Magnopotamion or Hydrocharition-type vegetation (Natura 2000 code of habitats: 3150) and lakes or dirty grey to blue - green water ponds, more or less turbid, especially rich in basic substances ( $\mathrm{pH}$ usually higher than 7), many freely floating Hydrocharition communities being present at the surface or, in case of the deep systems and open water surfaces, the Hydrocharition communities are associated to the submersed vegetation formed of large cormophytes (Magnopotamion) (Figure 9). 

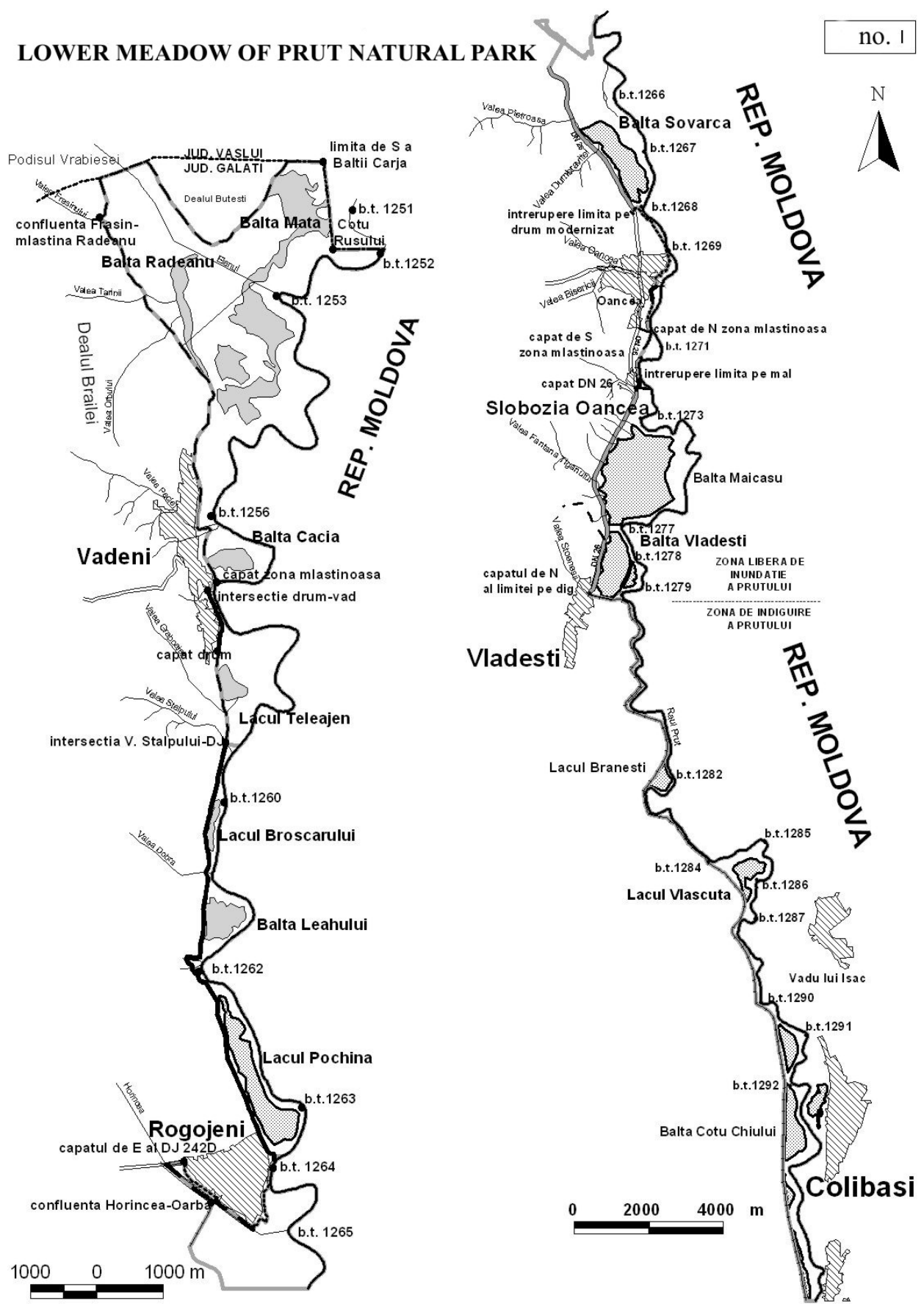

Figure 6. Northern part of Lower Meadow of Prut Natural Park 
LEGENDA

other type of limits

A limit on county border

limit on channel river

limit on dams

limit on modernized roads

limit on unmodernized roads

limit on international border

limit on forest edge

limit on permanent river bank

1. limit on lake bank

/ limit on swamp edge

- b.t. - topographical terminal

- b.s. -forest terminal

- river miles

$\rightarrow$ bridge

$\checkmark$ river network

railways

lake

DV locality

VIIA forest plot included in special protection area of Park

land-use other than forest included

in special protection area of Park

Danube Delta Biosphere Reservation

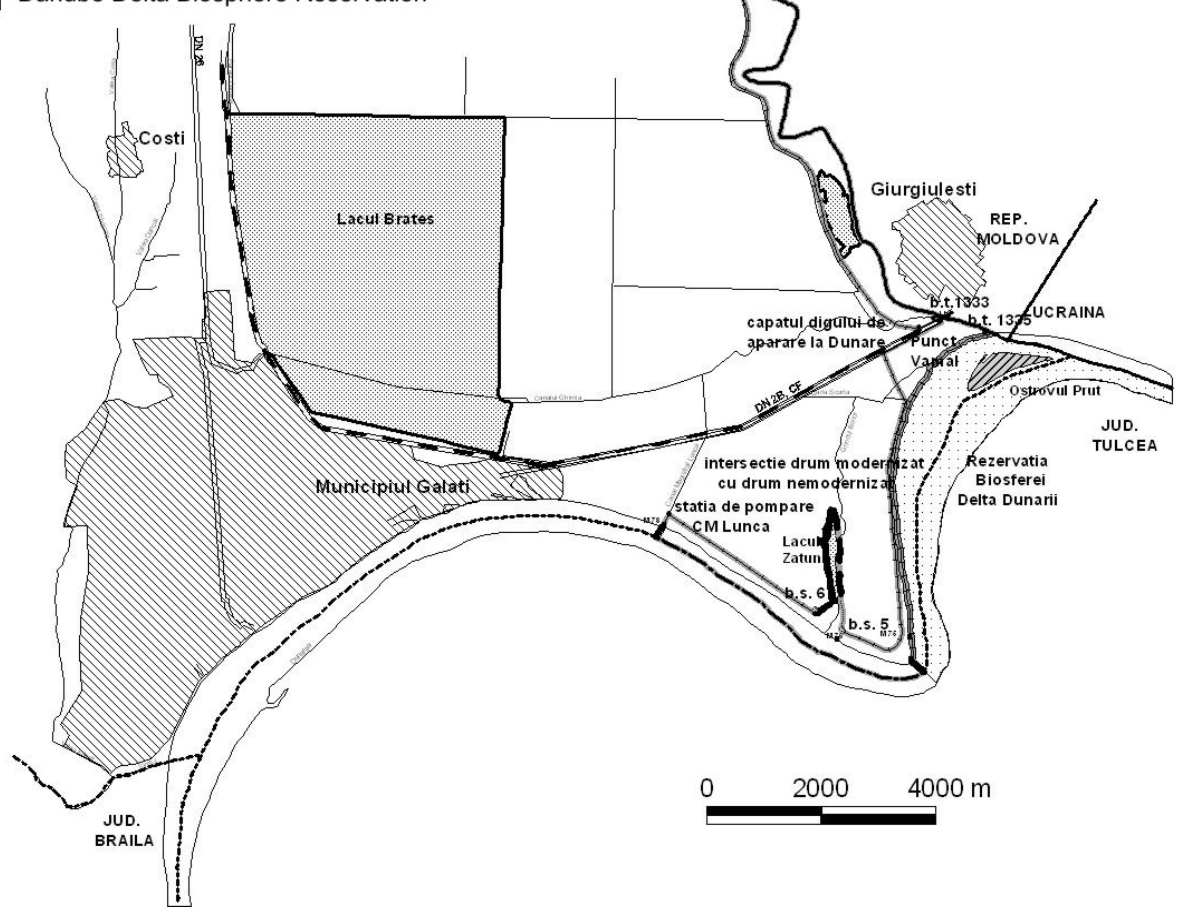

Figure 7. Southern part of Lower Meadow of Prut Natural Park 


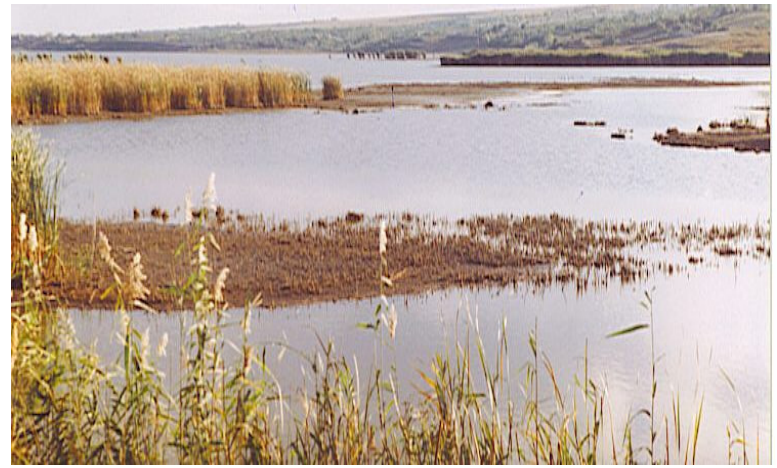

Figure 8. Biodiversity aspect in Mata-Radeanu complex of lakes

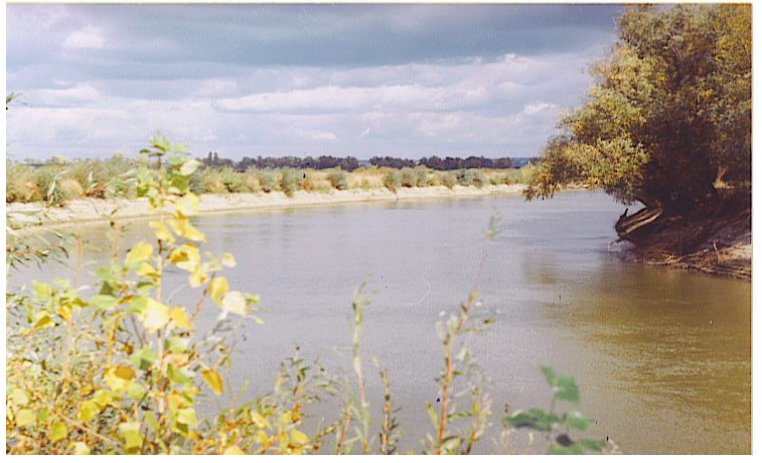

Figure 9. Natural potential for touristic activities in Lower Meadow of the Inferior Prut River Natural Park

The specific plants of the area are the duck weed (Lemna, Spirodella, Wolffia), Hydrocharis morsus - ranae (frog bit), Stratiotes aloides (water soldier), species of bladderwort (Utricularia australis, Utricularia vulgaris, etc.), Aldrovanda vesiculosa (waterwheel plant), ferns of Azolla type, aquatic moss of Riccia and Ricciocarpus types, different submersed cormophytes like the species of shining pond weed, such as Potamogeton lucens, Potamogeton praelongus, Potamogeton zizii, Potamogeton perfoliatus, etc.

\subsection{The description of special preservation areas}

The Lower Meadow of Inferior Prut River Natural Park includes all the flood meadow of Prut river on the administrative territory of Galați county. The Lower Meadow of Inferior Prut River Natural Park has the endorsement of CMN 19/Cj/18.02.2003. The planning maps of UP V Prut Meadow were drawn up by SILVAPROIECT, in 1995.

The special preservation area of the Lower Meadow of Inferior Prut River Natural Park includes: Brateş lake, including the fishery and the reed area and paludicolous vegetation, etc.; Prut Isle, with u.a. 82 from UP V Prut Meadow of OS Galaţi, between forest landmarks 
166 and 167; the area with dams of Prut river between Giurgiuleşti customs point, (topographical landmark 1333 on Prut river and the forest landmark 23, OS Galați) and Vlădeşti (topographical landmark 1297 on Prut river) which includes the forest plots and subplots 11 - $81 \mathrm{~A}$, including lakes, ponds and reed area.

The flood area of Prut river that includes Pochina - Rogojeni lake, including the associated reed area and paludicolous vegetation, and Vădeni area located between the junction of Stâlpului stream with Prut river (Figure 10).

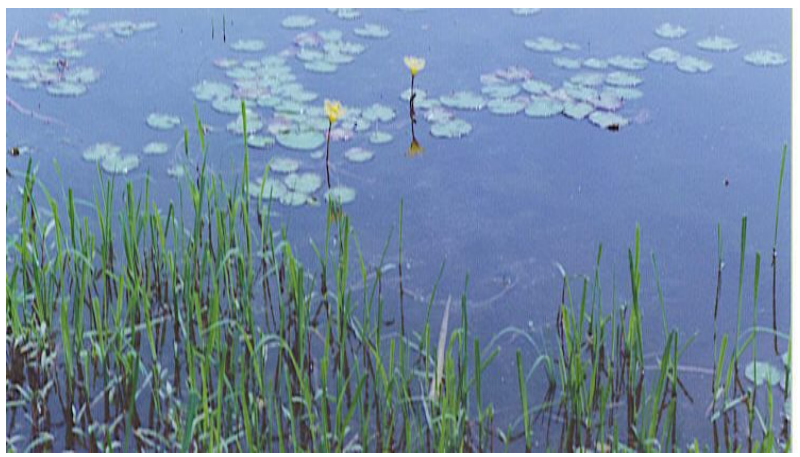

Figure 10. Biodiversity aspect in Pochina lake area

This lake is on the north border of Galaţi county with Vaslui county, between topographical landmarks 1260 and 1252, on Prut river, which includes Teleajen lake and Cacia, Mața and Rădeanu Ponds and the reed areas, agricultural surfaces, meadows and border forests; the area of Prut river between the river bank and the thalweg of the water flow on a distance of $122.4 \mathrm{~km}$, between the junction of the Danube right next to the forest landmark 21, OS Galați, respectively the topographical landmark 1335, on Prut river, and the topographical landmark 1252, from Cotu Rusului, on Prut river [14].

\section{Proposal for wetland management and solutions}

We propose the following potential demonstration sites for wetland management and restoration projects in the Lower Prut basin:

- Prut flood plain, downstream of Sovarca swamp, up to the mouth point in the Danube;

- Brates Lake located NE from Galați city, connected with the Prut.river by the valley of Ghimia brook;

- Horincea hydrographical basin (Figure 11).

Based on the analysis of the premises and conclusions that have emerged there can be extracted a series of proposals to solve the problem. The most important aspects are the technical (technical works for effective exploitation of water resources and the role improvement works combined with fish farming biotechnology) and organizational ones (decision-makers involved and the specific tasks) [15]. 


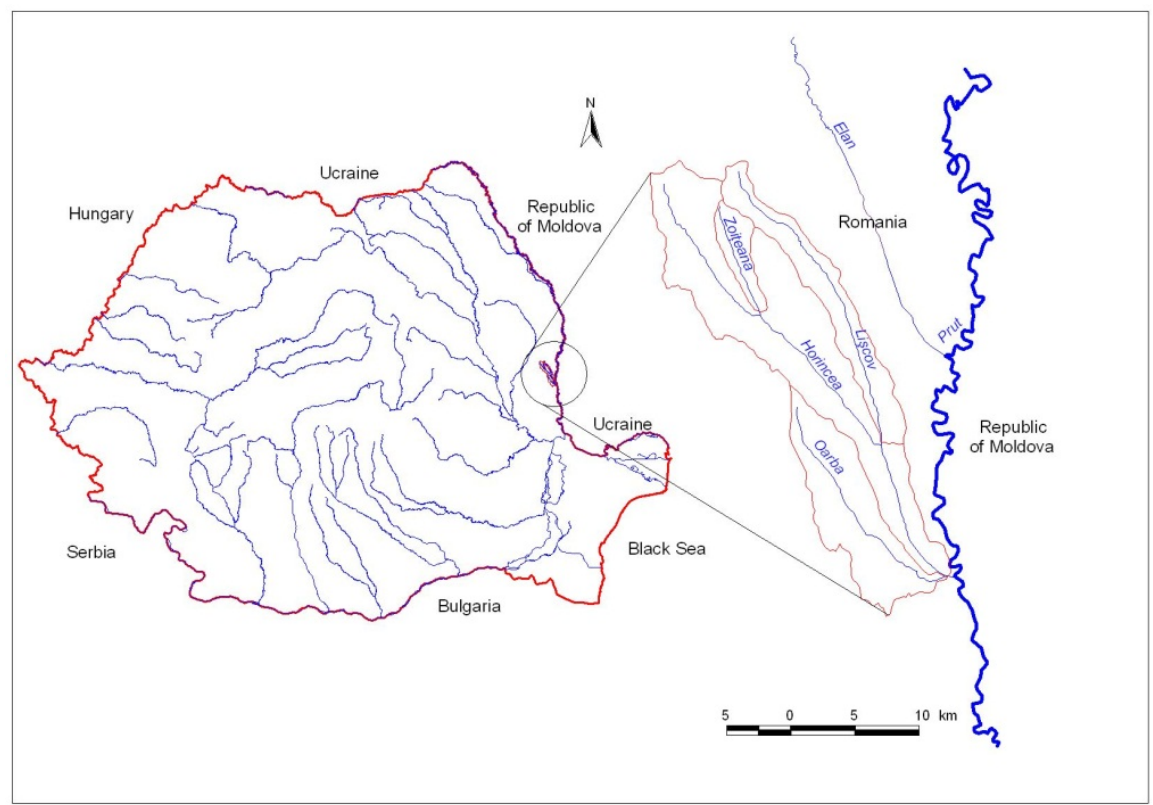

Figure 11. Location of Horincea sub-basin

\subsection{Technical aspects}

Rivers crossing the plain area as is it is the case of Prut river are not adequate for the partitioning of the river bed of their basins, because of the hydrologic regime with large flow variations. They may however be used as power sources for the system units created as a result of improvement works on the former marshes or for natural marshes as well as for economic and social utilities. Water use in these two cases requires the installation of pumping stations in the Giurgiulesti Oancea-area location, water and wastewater treatment. Their location will be dictated by the population exodus from town to village and the development of small rural industries.

The hydro potential of the sub-basins of this stream opens the door to elaborating an unified scheme in line with landscape features, hydrology and geology of the area. In this respect a complex arrangement of Horincea subbasin, Oancea, Bisericii and Stoenesei valleys which are located in an area of moisture deficit becomes essential. To complete the sub-basin planning, they should be viewed as indivisible natural units.

Developing works on these basins should start from the watershed line and include all works required for combating and preserving soil erosion and the total elimination of the harmful effects of the flood water. The accumulation of water thus created can store the flood waves and can also have a complex use: agro-fishery, water supply for livestock farms, for recreation. 
Regardless of the type of use, they must perform the following functions: to not allow the water flooding downstream, to ensure a guaranteed minimum flow during periods of low fluid potential and to ensure efficient use of water resources. Possible locations of accumulation for Horincea sub-basin can be completed in a subsequent step, with accumulations in its lower sector thereby ensuring effective control of the flow of the whole basin. The investment costs will be higher because of the fact that in this area Horincea stream has a riverbed requiring a dam of approximately $6 \mathrm{~km}$. Another future possibility would be that of transferring water from Prut although it would involve higher costs. This option would be justified in case the population in this area will grow up and small industry would develop.

The entire range of hydrotehnical works in the sub-basin Horincea of Oancea, Bisericii and Stoenesei valleys aimed at regulating the water stream in order to to avoid negative effects of flooding must nevertheless respect the principles of ecological planning in order to avoid failures occurring after the completion of this type of works respectively: the disappearance of flooded area which increases the speed of the water drainage because of the fact that the river beds, after the improvement works are performed, they become channels, thus the riparians can only use the water for a short time; increasing speed also leads to a gradual deepening of the river causing a general lowering of groundwater in the area leading to depletion of water from wells and land dryness.

When considering the environmental planning, one should start from the principle that the streams in the Prut basin represent simultaneously ways of circulation, tanks and complex ecological zones which are in strict interaction with the surrounding areas. Based on the data presented so far, respectively the abiotic and biotic components of the climatic, hydrologic regime, soil structure, vegetation, the intensity of erosion processes, profiles, the first steps that are recommended are: cutting the steep banks, which immediately reduces erosion, creating low gradient banks, stabilization of river' s bottom current by adding of rocks and boulders and planting both grass and shrub vegetation on the banks in order to stabilize the soil.

Regarding fisheries ponds built on the old marshes that belonged to the lower basin of the Prut River - they need to be restructured to ensure the optimal application of new technologies that are characteristic to the competitive business environment specific and market economy. The restructuring of fisheries facilities take the following general technical aspects:

- Sensible dimensioning of fishery farms to focus on technological activity on small areas of, easier to control and more effective;

- Use of hydraulic pressurized systems for the water supply of the units;

- Mechanization of the main technological phases for fishing, nutrition, maintenance using recirculation systems for intensive fish farming.

The restructuring of fisheries facilities open the prospect of achieving some strategic objective of the sector, namely: the application intensive fish farming of the valuable species 
in demand on the internal and external markets, the application of biotechnology in acclimatised spaces, mechanization and automation of piscicultural technologies.

Regarding the natural marshes that can still be found in the Prut meadow the best solution would be that they preserve their current form and they should become natural reservations. Preserving these areas will lead to the conservation of the biological balance and biodiversity of the area. Moreover, under the present circumstances, opens the perspective towards a new approach: the Prut meadow would enter the international circuit of protection and development.

\subsection{Organisational issues}

The central authorities that have specific responsibilities in environmental protection are the Ministry of Agriculture and Rural Development, Ministry of Environment and Forests and the two national companies - Romanian Waters National Company and National Company Romsilva).

Ministry of Environment and Forests has major responsibility for environmental protection in Romania, its main tasks being related to water management of river basin planning for the reclaim of new water sources, coordinates the preparation of plans and frameworks for developing the hydrographical basins, approves the water-related works, establishes forecast and information activities in the field of water management and hydrology, etc.

Ministry of Agriculture and Rural Development has specific responsibilities the field of protection of soil, terrestrial and aquatic ecosystems. Also, it elaborates and sets up priority programs for improvement of works and financing, preventing and combating animal diseases, plant protection and phyto-sanitary quarantine, quality control of seeds and seedlings.

This ministry approves land improvement, conservation and environmental protection programs and it elaborates regulations regarding agricultural systems, technologies of plant cultivation and animal husbandry, forest regeneration, harvesting, collection and transport, and soil quality standards in order to maintain and improve it, to remove the negative consequences on aquatic and terrestrial ecosystems to ensure conservation of specific functions, biodiversity and natural habitats, and communicates with the central environmental authorities.

Ministry of Agriculture and Rural Development keeps track of land rendered unfit for agricultural production and provides upon the request of their owners specialized technical assistance for land improvement works.

Romanian Waters National Company manages water resources (surface and groundwater) and prepares and monitors the implementation of programs for meeting the water demands of the population and economy, exploitation of new water sources, rational use and protection 
against depletion and pollution, complex planning of water in accordance with current and future requirements. It is also the Romanian Waters National Company that correlates the water works with land reclamation works.

National Forest Company Romsilva is required to perform all the works of ecological restoration, regeneration, plantation and maintenance.

\subsection{Law aspects}

In Legislation of many states definition "Natural Environment” was transfonned through last decade into "Naturally-Anthropogenic" one. This change reflects attempts to find more precise equilibrium between the present-economical development and future generation's survival [16].

River basins became the main "indicators" to attain such equilibrium. And their problems are focal for further Sustainable Development (and for success of concrete modern approaches, such as Spatial Planning, Environmental Management, Technology Foresight, Pollution Prevention, Cleaner Production, Eco-efficiency, Life Cycle Assessment etc.

For Water Management Systems on the cross-border flows this reality brings up a huge knot of multilevel problems. Their step-by-step resolution will be possible when, instead to struggle with consequences, authorities of all levels will do away with causes.

Further absence if causal-investigatory connections between the economical and environmental aspects in this area as well as in activity of authorities will aggravate the situation.

Therefore the "survival" of existent and new enterprises under the new conditions as well as their attraction for necessary investments and international support, will directly depend of systems accounting, appraisal, risks assessment and Audit implementation.

Today in Lower Prut basin there are some examples of the enterprises reporting completely harmonised with the EU regulations. But parallel to the Environmental Inspectors the separately collected data is referred to other control bodies (Sanitary Service, Workmen's Protection, Emergency Planning, Statistics Office, Municipal Structures, Water Management etc.). But at the source of information is absent the interior self-organisation accordingly to the "process approach", foreseen by International Standards of Quality ISO 9000:2000 and Environmental Management ISO 14000.

Other experience such as Ukrainian-Austrian-Romanian former project already demonstrate, that such approach is profitable for the enterprises, regional executive authorities and local self-Governments, whereas it concentrates limited resources for the key (weak) points and sectors. And simultaneously it generates a good opportunity for joint revealing and agreement of win-win solutions [17].

On the other hand the same principles becomes now a basis for safe development of business and investments in the Eastem Europe, today and in the future as well. 


\section{Irrigations and works for this purpose in lower Prut basin related to wetlands}

The total surface included in the irrigation system in the Prut catchment area is about 100,000 ha and the drainage systems is about 130,000 ha.

In the irrigation system about $40,000 \mathrm{mc}$ water are used, which are contributing to the groundwater sources increase. The dykes created near the river have reduced the floodplain wetlands, has disconnected the land from the river and creates problem with salinity and stepisation.

A part of the reservoirs mentioned above are used for water supply for irrigations. Other sources are the rivers and groundwater from the region and for distribution a large network of channels and ditches were constructed in the years 70s and 80s.

This has influenced the water flow regime as well as the supply of wetlands and floodplains of the river.

As a result of the drainage and irrigation systems created 2/3 of the Lake Brates (located in soth part of the basin) has disappeared its well as a lot of swamps, meadows, reed beds, which represented habitats for a high biodiversity, especially because it was closed located to another big wetlands Danube Delta and the Danub-Macin complex [18].

This was mainly happening inside of the protected area, in the agricultural land.

In the management plan for wetlands as well as in the proposal for future actions these channels are proposed for creations of micro-area for nature conservation. Fortunately a floodplain area was saved having about 5,000 ha in the lower part of Prut and located between embankments and river which in some places has few hundred meters width.

This is characterized by a flood plain with good water dynamics, flood plain gallery forest with different species, floodplain small lakes with macrophytes, meadows and reed beds which still preserves a number of birds and animal species, but which is characterized by a mainly economically-oriented management and less in the favor of biodiversity.

A recent study produced by WWF Danube - Carpathian Programme within the Danube Pollution Reduction Programme has indicated that about 51,000 ha. are possible to be restored in the locations of the previous wetlands and flood plains from the lower Prut area.

This will allow the restoration of floodplain by reconnecting areas to the water river dynamics having as effect improvement of water quality, restoration of wetland vegetation and biodiversity conditions enhancement.

\section{Effects of anthropogenic activities on wetlands and floodplains}

The human pressure has been led to the changes of structure and functionality of the wetlands floodplains and of the Prut river, characterized through the apparition of a strongly anthropizated environment [19]. 
The key issues of anthropogenic activities which have had effects on wetlands and floodplains of the river Prut are represented in table 8.

Regarding the industrial and diffuse pollution which have an impact on Prut ecology and water quality, this being closely linked with the ecology of the floodplain forested corridor and the existing wetlands, the situation is much severe in the upper part of the basin, based on a large concentration of industry, agriculture and human settlements in comparison with the lower Prut where the impact is much smaller.

\begin{tabular}{|c|c|}
\hline Key issues & Impact \\
\hline $\begin{array}{l}\text { Hydrotechical works and reservoirs } \\
8 \text { non-permanent or semi-permanent } \\
\text { reservoirs which keep } 40 \text { million } \mathrm{m}^{2} \\
329 \mathrm{~km} \text { of embankments along of } 480 \mathrm{~km} \\
\text { banks on the Prut river and some } \\
\text { tributaries to protect of near } 100.000 \text { ha of } \\
\text { agricultural land, } 25 \text { localities and } 120 \\
\text { industrial units. }\end{array}$ & $\begin{array}{l}\text { Reduction of wetlands and floodplains. } \\
\text { Reduction of efficiency of nutrients sink. } \\
\text { Reduction of the water running area of the } \\
\text { river which increases the flow velocity and } \\
\text { affects the flood forest and embankments. } \\
\text { Reduction of water quality self-dynamics. } \\
\text { Reduction of suspended solids transport } \\
\text { efficiency. } \\
\text { Increasing of erosion un downstream areas. } \\
\text { Decreasing of groundwater recharge } \\
\text { capacity. } \\
\text { Water shortages. } \\
\text { Disappearance of diverse habitats which } \\
\text { offered life conditions for a high vegetal and } \\
\text { animal. Birds biodiversity. } \\
\text { Decrease of economical (fisheries, wood, } \\
\text { reeds, hunting) and touristic potential. } \\
\text { Disappearance of micro - climate effects. }\end{array}$ \\
\hline Agriculture and rural land use & $\begin{array}{l}\text { Increase of nutrients concentration in river } \\
\text { water. } \\
\text { Increase of toxic substance loads. } \\
\text { Salinisation. } \\
\text { Stepisation. } \\
\text { Disappearance of swamps, meadows, reed } \\
\text { beds. }\end{array}$ \\
\hline Fisheries & $\begin{array}{l}\text { Disappearance of spawning conditions. } \\
\text { Reduction of fish quantity. } \\
\text { Reduction of economically high quality } \\
\text { species. }\end{array}$ \\
\hline
\end{tabular}

Table 8. The key issues of anthropogenic activities which have had effects on wetlands and floodplains 


\section{Conclusions and recommendations about biodiversity protection and water resources management in lower Prut basin}

In present we recommend that surveys are carried out to evaluate the current state of biological and landscape diversity of the lakes, especially those with ornithological importance and so that a long-term integrated monitoring system is devised for the lakes and wetlands in the Lower Danube Region.

Also it is recommend that scientific evidence is compiled for assigning nature conservation status to Lakes Kagul, Kartal, and Kugurlui and prepare proposals for designating Lake Kagul as a wetland of international significance, so that the point and non-point sources of pollution in the lake basins are identified and assessed.

At least we recommend that dynamic modeling is used as an aid for lake management taking full account of any inherent limitations in such models.

The spirit of Environment protection Law and Water Law seen as interior documents for each enterprise aimed to order their own knowledge about the flows of waste (losses, sewage, discharges and package materials). The general outside task of this study becomes the universal primary source of information for further accounts to Environmental and Water Management Structures, Emergency Planning, Labour Safety, Sanitary and Municipal Services, Statistics Office etc.

In general, the implementation of this study is the first step, which brings together the interests of the enterprises, Local, Regional and National authorities for the Natural Resource Conservation, safe Water Management and Waste Minimisation and Competitiveness of Productions and Services as core elements of Sustainable Spatial Development in Lower Prut basin.

\section{Author details}

Florin Vartolomei

Faculty of Geography, SPIRU HARET University, Bucharest, Romania

\section{References}

[1] Bălteanu D., Badea L., Buza M., Niculescu Gh., Popescu C., Dumitraşcu Monica (eds.), Romania. Space, Society, Environment, Romanian Academy Publishing House, Bucharest, ISBN 973-27-1275-9, 2006.

[2] Pop Iuliana, Madalina-Teodora Andrei, Charlotte-Valentine Ene, Radita Alexe, Florin Vartolomei, Petronela-Sonia Nedea, The strategy of European Union regarding climate change in International Journal Of Energy And Environment, Issue 4, Volume 5, 2011, ISSN 1109-9577, pp. 558-565.

[3] Pop Iuliana, Madalina-Teodora Andrei, Charlotte Valentine Ene, Florin Vartolomei, Petronela-Sonia Nedea, Radita Alexe, E.U. environmental policies: a document-based 
qualitative research, in Recent researches in Energy \& Environment, Cambridge, U.K., February, 2011, ISBN 978-960-474-274-5, ISSN 1792-8230, pp 372-377.

[4] Florin Vartolomei, Măsuri superioare de protecție a biodiversităţii naturale în bazinul hidrografic Prut, in Revista Mediul Inconjurător, no. 1 din 2006, pp. 59-65, ISSN 14533944, Bucureşti, 2006.

[5] Florin Vartolomei, Parcurile Naturale şi Naţionale ale României, in Geograful, no. 2, pp. 25-35, www.apgr.eu, ISSN 2067 - 4090, e-ISSN 2068-9977, Bucureşti, 2010.

[6] Florin Vartolomei, Stabilirea limitelor ariilor protejate prin utilizarea tehnicilor G.P.S. şi G.I.S. Studiu de caz: Cheile Lucavei-jud. Suceava, in Volumul de Rezumate al Sesiunii anuale de comunicări ştiinţifice a Institutului de Speologie Emil Racoviţă din cadrul Academiei Române, intitulată "85 de ani de la înfiinţarea Institutului de Speologie Emil Racoviță", pp. 24-25, ISBN 973-0-04349-3, Bucureşti, 2006.

[7] Florin Vartolomei, Despre utilizarea tehnicilor GPS la stabilirea limitelor ariilor protejate din România, in Revista Mediul Înconjurător, Nr. 1 din 2003, pp. 40-44, ISSN 1453-3944, Bucureşti, 2003.

[8] Florin Vartolomei, Rezervațiile naturale din bazinul hidrografic al Prutului, in Annals of SPIRU HARET University Geography Series, No. 5, pp. 135-140, ISSN 1453-8792, Bucureşti, 2002.

[9] Florin Vartolomei, Corneliu Râclea, Arii naturale protejate şi monumente ale naturii din județul Vaslui, ISBN (10) 973-87523-5-3; ISBN (13) 978-973-87523-5-1, Edit. Mondoro, Bucureşti, 2006.

[10] Vartolomei Florin, Madalina-Teodora Andrei, Iuliana Pop, Petronela-Sonia Nedea, Radita Alexe, Biodiversity protection actions in lower Prut basin, in International Journal Of Energy And Environment, Issue 5, Volume 5, 2011, ISSN 1109-9577, pp. 678-685.

[11] Florin Vartolomei, Aspecte asupra calităţii apei în acumularea Stânca-Costeşti (bazinul hidrografic Prut), in Annals of SPIRU HARET University Geography Series, No. 6, pp. 5964, ISSN 1453-8792, Bucureşti, 2003.

[12] Florin Vartolomei, Environment integration of ecological and biological influences in the lakes from lower section of Prut river, in Romanian Journal of Limnology "Lakes, reservoirs and ponds", Editura Transversal, nr. 1-2, pp. 157-165, ISSN 1844-6477, Târgovişte, 2008.

[13] Florin Vartolomei, Tehnici G.I.S. utilizate la valorificarea potenţialului turistic natural în bazinul hidrografic Prut, in Revista Simpozionului cu participare internatională de la Universitatea Româno-Americană "Turismul durabil românesc în contextul integrării economice europene", ediție pe CD, ISBN (10) 973-8994-67-5, ISBN (13) 978-973-8994-67-6, pp. 225-237, Bucureşti, 2006.

[14] Mădălina Andrei, Florin Vartolomei, Landscape's evolution. GIS application approach, in Applied Geography in Theory and Practice, Book of Abstracts, International Scientific Conference, 5-6 Noiembrie 2010, Universitatea din Zagreb, Facultatea de Ştiințe Departamentul de Geografie, p. 27, ISBN 978-953-6076-22-2, Zagreb, 2010. http://atlas.geog.pmf.hr/ nbuzjak/konf/Zagreb2010_Abstracts.pdf

[15] Vartolomei Florin, Radita Alexe, Madalina-Teodora Andrei, Petronela-Sonia Nedea, Iuliana Pop, Development of a pilot wetland area to protect biodiversity in the southern 
basin of Prut river, in Recent researches in energy, environment, devices, systems, comunications and computers, Venice, Italy, March, 2011, ISBN 978-960-474-284-4, ISSN 1792-863X, pp 112-117.

[16] Florin Vartolomei, Mădălina-Teodora Andrei, Legislaţia pentru protecția factorilor de mediu din România, cu privire specială asupra biodiversității, in Volumul Simpozionului cu participare internațională al Universității Româno-Americane, 7-8 noiembrie 2008, Bucureşti, intitulat "Performanţă, riscuri şi tendințe în turismul mondial", Editura ProUniversitaria, pp. 159-169, ISBN 978-973-129-326-4, Bucureşti, 2008.

[17] Florin Vartolomei, Natural protected areas from Vaslui county, in Annals of SPIRU HARET University Geography Series, No. 10, pp. 163-168, ISSN 1453-8792, Bucureşti, 2007.

[18] Bălteanu D., Dumitraşcu Monica, Ciupitu D., Maxim I., România, Ariile naturale protejate, Map 1:750 000 scale , Editura CD Press, Bucureşti, 2009.

[19] Surd Vasile, Veronica Constantin, Camelia-Maria Kantor, Strategic vision and concept of regional planning and sustainable development in Romania based on the use of geospatial solutions, in International Journal Of Energy And Environment, Issue 1, Volume 5, 2011, ISSN 1109-9577, pp. 91-101. 